University of Nebraska - Lincoln

DigitalCommons@University of Nebraska - Lincoln

USDA National Wildlife Research Center - Staff Publications
U.S. Department of Agriculture: Animal and Plant Health Inspection Service

2017

\title{
EVALUATING THE IMPACT OF AN EXOTIC PLANT INVASION ON RODENT COMMUNITY RICHNESS AND ABUNDANCE
}

Trinity N. Smith

Utah State University, trinitysmith10@gmail.com

Eric M. Gese

Utah State University

Bryan M. Kluever

Utah State University

Follow this and additional works at: https://digitalcommons.unl.edu/icwdm_usdanwrc

Part of the Life Sciences Commons

Smith, Trinity N.; Gese, Eric M.; and Kluever, Bryan M., "EVALUATING THE IMPACT OF AN EXOTIC PLANT INVASION ON RODENT COMMUNITY RICHNESS AND ABUNDANCE" (2017). USDA National Wildlife Research Center - Staff Publications. 2062.

https://digitalcommons.unl.edu/icwdm_usdanwrc/2062

This Article is brought to you for free and open access by the U.S. Department of Agriculture: Animal and Plant Health Inspection Service at DigitalCommons@University of Nebraska - Lincoln. It has been accepted for inclusion in USDA National Wildlife Research Center - Staff Publications by an authorized administrator of DigitalCommons@University of Nebraska - Lincoln. 


\title{
EVALUATING THE IMPACT OF AN EXOTIC PLANT INVASION ON RODENT COMMUNITY RICHNESS AND ABUNDANCE
}

\author{
Trinity N. Smith1,3, Eric M. Gese ${ }^{2}$, and Bryan M. Kluever ${ }^{1}$
}

\begin{abstract}
Cheatgrass (Bromus tectorum), Russian thistle (Salsola kali), and tall tumblemustard (Sisymbrium altissimum) are nonnative plants widely distributed throughout the desert and shrubsteppe communities of the western United States. The impact of these invaders on plant community structure, form, and function has been well documented, but investigations determining the impacts of this cumulative invasion on terrestrial vertebrates have not been undertaken. Our objective was to assess community-level rodent responses to changes in plant community features, with an emphasis on dominance of invasive plant species. We sampled rodent and plant communities in the Great Basin Desert (Utah) over 4 years. Using estimates of rodent species richness and average nightly captures (relative abundance) as our response variables, we developed generalized linear mixed models (GLMMs) to determine the effects of invasive species cover. We found that rodent richness decreased with increasing abundance of invasive plant cover. Contrary to other studies, there was a nonlinear relationship between invasive species cover and rodent abundance, where rodent captures increased with invasive plant cover, reached a threshold, and then exhibited a negative response. This nonlinear relationship provides support for the intermediate disturbance hypothesis and suggests that moderate levels of plant invasions, by way of bolstering rodent abundance and rodent biomass, could have bottom-up effects (i.e., positively influencing species that predominantly prey upon rodents). Our findings contradict previous findings on plant invasions in arid portions of the western United States and suggest that the species comprising or dominating a given rodent community may determine the impact of plant invasions.
\end{abstract}

RESUMEN.-Bromus tectorum, Salsola kali y Sisymbrium altissimum son plantas no nativas ampliamente distribuidas por todo el desierto y las comunidades de estepas arbustivas del oeste de los Estados Unidos. El impacto de estas especies invasoras en la estructura, forma y función de la comunidad vegetal ha sido bien documentado, sin embargo no se han llevado a cabo investigaciones que determinen los impactos de esta invasión acumulada en vertebrados terrestres. Nuestro objetivo fue evaluar las respuestas de los roedores a nivel comunitario a los cambios en las características de la comunidad vegetal, con énfasis en la dominancia de las especies de plantas invasoras. Muestreamos comunidades de roedores y plantas en el desierto de la Gran Cuenca (Utah) durante cuatro años. Utilizando estimaciones de la riqueza de especies de roedores y las capturas promedio por la noche (abundancia relativa) como nuestras variables de respuesta, desarrollamos modelos lineales generalizados mixtos (GLMM) para determinar el efecto de la cobertura de especies invasoras. Encontramos que la riqueza de los roedores disminuyó con el aumento de la abundancia de la cobertura vegetal invasora. Contrario a otros estudios, encontramos una relación no lineal entre la cobertura de especies invasoras y la abundancia de roedores, donde las capturas de roedores aumentaron con la cobertura de plantas invasoras, alcanzando un umbral y luego presentando una respuesta negativa. Esta relación no lineal proporciona apoyo para la hipótesis de perturbación intermedia y sugiere que los niveles moderados de invasiones de plantas, a modo de reforzar la abundancia de roedores y la biomasa de roedores, podrían tener efectos ascendentes (es decir, influir positivamente en las especies que predominantemente se alimentan de roedores). Nuestros hallazgos contradicen los hallazgos previos sobre invasiones de plantas en zonas áridas del oeste de los Estados Unidos, y sugieren que las especies que comprenden o dominan una determinada comunidad de roedores pueden determinar el impacto de las invasiones de plantas.

Ecosystem viability is often assessed by monitoring community metrics, such as richness and abundance, at differing clades and trophic levels (Tilman et al. 1997, Niemi and McDonald 2004, Balvanera et al. 2014). As invasive plant species colonize native vegetation communities, ecosystems are often dramatically changed (Tilman et al. 1997, Reisner et al. 2013, Steidl et al. 2013). Arid shrublands and grasslands throughout the western United States have been particularly impacted by invasive species, as changes in grazing and fire regimes have buttressed the establishment of annual grass species such as cheatgrass (Bromus tectorum), medusahead (Taeniatherum caput-medusae), and red brome (Bromus rubens) (Knapp 1996, Chambers 2008, Litt and Pearson 2013, Steidl et al. 2013). Of the

\footnotetext{
${ }^{1}$ Department of Wildland Resources, Utah State University, Logan, UT 84322-5230.

${ }^{2}$ United States Department of Agriculture, Wildlife Services, National Wildlife Research Center, Department of Wildland Resources, Utah State University, Logan, UT 84322-5230.

${ }^{3}$ E-mail: trinitysmith10@gmail.com
} 
annual grass species, cheatgrass has been a particularly successful invader in the western United States. Since the species' introduction in the early 1900s, cheatgrass has been able to propagate due to its ability to saturate the understory, and continuous cheatgrass monocultures are often the eventual result (Young et al. 1987). This dramatic community alteration decreases plant species richness and abundance (Hejda et al. 2009, Freeman et al. 2014) and reduces functional plant diversity (Hejda et al. 2009, Steidl et al. 2013). Once desiccated, these monocultures act as ideal fuel and increase the frequency of fire, which perpetuates further establishment of the grasses and other invasive forbs across the landscape (Reisner et al. 2013).

Exotic forbs such as Russian thistle (Salsola kali) and tall tumblemustard (Sisymbrium altissimum) are also widely distributed across the Great Basin (Yensen 1981). Commonly known as tumbleweeds, the prolific seeding habits of these forbs make them successful invaders with the potential to outcompete native plants, especially in previously disturbed sites (Yensen 1981). The combined invasion of the aforementioned species is responsible for the elimination of large areas of sagebrush-bunchgrass and mixed shrublands throughout the western United States (Yensen 1981, Knapp 1996, Chambers 2008, Litt and Pearson 2013, Reisner et al. 2013).

Plant invasions can cause cascading effects for higher trophic levels, especially in sagebrush-bunchgrass habitats (Ostoja and Schupp 2009, Steidl et al. 2013, Freeman et al. 2014). Monocultures often alter habitat heterogeneity (Knapp 1996) and reduce quality of available forage for rodents and other herbivores (Reisner et al. 2013). This reduction in habitat and forage can cause a bottom-up effect, lowering animal diversity and abundance at higher trophic levels (Knapp 1996, Ostoja and Schupp 2009, Fischer et al. 2012, Litt and Pearson 2013, Steidl et al. 2013, Freeman et al. 2014, Zeng et. al. 2014). However, relaxed competition resulting from declines in diversity of invader-affected rodent species may shift rodent community assemblages, allowing remaining species to better utilize the resources and habitat characteristics provided by invasive plants (Kelt 2011). Investigations have revealed that plant invasions can increase the abundance of animal species that prefer dense vegetation or are able to utilize seed resources provided by invasive plants (Mattos and Orrok 2010, Malick et al. 2012, Malo et al. 2013, Litt and Pearson 2013, Steidl et al. 2013). Increasing our understanding of the effects of biological invasions on highertrophic-level species and communities is vital to informing decisions concerning wide-scale management and conservation actions, as exotic species invasions are forecast to increase (Sax et al. 2007, Litt and Pearson 2013, Steidl et al. 2013).

Rodent studies are often used as a tool for quantifying overall ecosystem function, since species in this clade are relatively easy to capture and quantify, have a large influence on the distribution of plants, and act as a pivotal food source for mammalian and avian predators (Sieg 1987, Kelt 2011). In addition to serving as prey, rodents act as ecosystem engineers by disturbing soil, caching and dispersing seeds, and preferentially consuming seeds (Olff and Ritchie 1998, Steidl et al. 2013). As a primarily granivorous guild, desert rodent communities are not exempt from the myriad changes caused by plant invasions (Freeman et al. 2014). Typically, diverse communities have been observed in areas with high levels of structural heterogeneity, with less dense groundcover and a mosaic plant community (Ostoja and Schupp 2009, Hall 2012, Steidl et al. 2013, Thompson and Gese 2013). This is of particular concern because structural heterogeneity is reduced by plant invasions (Litt and Pearson 2013, Reisner et al. 2013). A recent study across the Great Basin Desert found that total rodent abundance and richness decreased linearly with increasing cheatgrass cover, though total abundance was highly driven by the most ubiquitous species, the deer mouse (Peromyscus maniculatus) (Freeman et al. 2014). Similarly, Hall (2012) observed a negative linear relationship between cheatgrass density and abundance of deer mice.

Although nonnative plant invasions appear to lead ubiquitously to decreases in native fauna richness (Ostoja and Schupp 2009, Hall 2012), recent investigations have challenged the widely held viewpoint that invasive species invasions uniformly lead to reduced abundance of native animal populations. The intermediate disturbance hypothesis predicts an observable increase in species richness or total abundance following a moderate level of 
disturbance (Roxburgh et al. 2004). Several vertebrate communities have been found to respond in accordance with the intermediate disturbance hypothesis. For example, riparian bird communities responded positively to Russian olive (Elaeagnus angustifolia) invasion up to a threshold (Fischer et al. 2012), and reptile communities responded with increased total abundance following logging, with the highest abundance found around a median time since disturbance (Hu et al. 2013). Studies addressing this topic for rodent species and communities are mixed. Freeman et al. (2014) found that rodent abundance decreased with increasing cheatgrass cover. Conversely, a study on the influence of spotted knapweed (Centaurea stoebe) on a rodent community dominated by deer mice found that invasion had an indirect positive influence on rodent abundance because of an increase in food resources (Pearson and Fletcher 2008, Malick et al. 2012). Others have suggested that the effects of cheatgrass invasion on rodent abundance are species-dependent, whereby some species were more adversely affected than others (Ostoja and Schupp 2009, Litt and Pearson 2013, Steidl et al. 2013). These findings suggest that further examination of the impact of plant invasions on rodent communities is warranted.

The overall objective of our study was to further elucidate the influence of invasive plant species on rodent communities in the Great Basin Desert. Specifically, we aimed to determine (1) the impact of invasive plant species on rodent species richness and (2) the impact of invasive plant species on total rodent abundance. We predicted that we would observe linear decreases in rodent species richness and abundance in response to plant invasion severity.

\section{Methods}

\section{Study Area}

We sampled rodent and plant communities throughout the summers of 2010 through 2013 within $266 \mathrm{~km}^{2}$ of the eastern portion of the U.S. Army Dugway Proving Ground, located approximately $128 \mathrm{~km}$ southwest of Salt Lake City in Tooele County, Utah, USA. Elevations ranged from 1349 to $2021 \mathrm{~m}$. The area was characterized as a cold desert: winters were cold, summers were hot and dry, with the majority of precipitation occurring in the spring. Average maximum temperatures on DPG ranged from $3.3^{\circ} \mathrm{C}$ in January to $34.7^{\circ} \mathrm{C}$ in July (Arjo et al. 2007). Average minimum temperatures ranged from $-8.8^{\circ} \mathrm{C}$ in January to $16.3{ }^{\circ} \mathrm{C}$ in July. Mean annual precipitation was $20.07 \mathrm{~cm}$. The study area consisted of a predominately flat playa punctuated with steep mountain ranges. The lowest areas consisted of sparsely vegetated salt playa flats. Slightly higher-elevation areas were less salty and supported a cold desert chenopod shrub community dominated by greasewood (Sarcobatus vermiculatus). Higher elevations consisted of vegetated sand dunes. Near the bases of the higher, steep mountains were shrub-steppe communities of big sagebrush (Artemisia tridentata). The highest elevation was a Utah juniper (Juniperus osteosperma) community including black sagebrush (Artemisia nova) and bluebunch wheatgrass (Pseudoroegneria spicata). Exotic herbaceous vegetation, primarily cheatgrass, tall tumblemustard, and Russian thistle, had replaced approximately $40 \%$ of historical juniper woodland and shrub communities (Emrick and Hill 1999). These exotic plant species were also interspersed within communities dominated by sagebrush, rabbitbrush (Chrysothamnus sp.), greasewood, and juniper (Arjo et al. 2007).

\section{Data Collection}

We used stratified random sampling (see Kluever et al. 2016) to establish sixteen $50 \times$ 50-m sampling plots throughout the study area (Fig. 1). We evaluated the plant community using seven $60-\mathrm{m}$ line transects following the axis of the plot and spaced $10 \mathrm{~m}$ apart. The orientation of vegetation transects (e.g., east to west, north to south) was randomly chosen for each sampling event, such that the transects still overlapped the rodent trapping grid. Using the line-point intercept method (Herrick et al. 2005), we catalogued cover type, species encountered, and plant height at 1-m intervals. We sampled vegetation on plots twice per summer on the day prior to the onset of rodent sampling. This vegetation sampling protocol has been previously used to determine the effect of vegetation characteristics on rodent communities (Thompson and Gese 2013, Freeman et al. 2014). Parameters estimated from transects were percent bare ground, percent litter cover, mean plant height, percent 


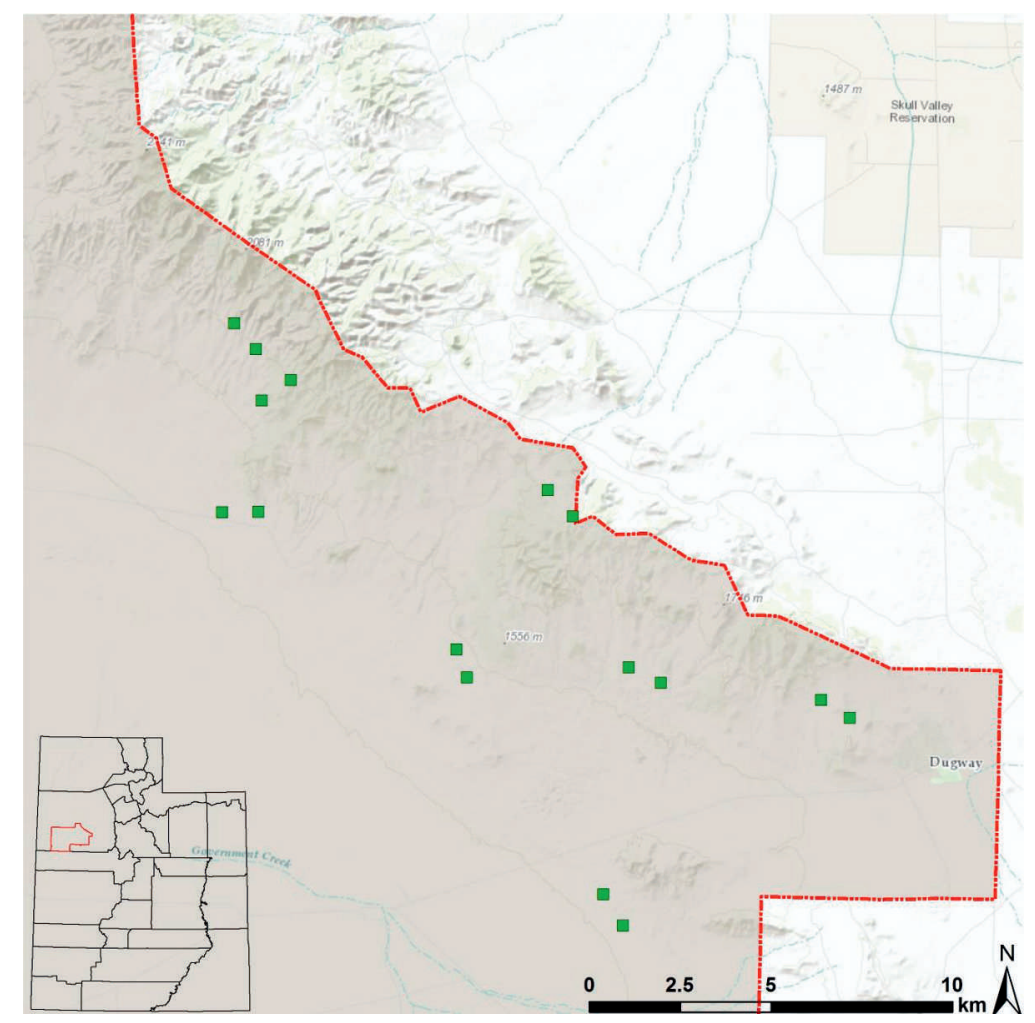

Fig. 1. Study area and sample plots (map created using ArcGIS, Esri, Redlands, CA). Green boxes denote the locations of sixteen $50 \times 50$-m trapping plots that were sampled for rodents on the U.S. Army Dugway Proving Ground, Utah, 2010-2013.

shrub cover, percent cheatgrass cover, and percent invasive species cover. We determined the percent cover of invasive species by using the combined occurrence of cheatgrass, tall tumblemustard, and Russian thistle.

We sampled rodents at each plot for 4 consecutive nights (i.e., one trapping session). Two trapping sessions took place each summer, typically with one in late spring/early summer (1 May to 30 June) and the other in late summer/early autumn (1 August to 30 September). During the first year of the study, 3 sampling sessions took place at each site, with 2 trapping sessions occurring during all other years. We established a $7 \times 7$ trapping grid (8.3-m spacing per trap) with Sherman live traps $(5.08 \times 6.35 \times 22.86 \mathrm{~cm}$; H.B. Sherman Traps, Inc., Tallahassee, FL) at each site. We were more interested in obtaining estimates of rodent community metrics at the scale of specific grids than an inventory of species at the landscape level. Thus, we followed the recommendations of Conard et al.
(2008) and used high-density Sherman live trap grids ( $\leq 11-\mathrm{m}$ spacing) and a moderate sampling duration (4 nights).

We baited traps with a mixture of black sunflower and mixed bird seed. All captured rodents were identified to species and standard morphometric measurements (e.g., mass, tail length, hind foot length) were recorded. Because moon brightness can influence foraging behavior and activity patterns of desert rodents (Kaufman and Kaufman 1982, Kotler et al. 2010, Upham and Hafner 2013), we recorded moon brightness for each trapping session as percent moon illuminated, following the methods described by Upham and Hafner (2013). We estimated species richness for all rodent plots by using the maximum number of species encountered during a given trapping session. We estimated rodent abundance by using the average number of nightly captures per session per grid, a metric often used as a reliable surrogate for abundance (Bowman et al. 2001, Thompson and Gese 2013, Young et al. 2016). 
Fieldwork was approved and sanctioned by the USDA National Wildlife Research Center and the U.S. Army Dugway Proving Ground. Permission to access land on the Dugway Proving Ground was obtained from the U.S. Army. Capture and handling protocols were reviewed and approved by the Institutional Animal Care and Use Committees (IACUC) at the USDA National Wildlife Research Center (QA-1734) and Utah State University (\#1438). All applicable institutional and national guidelines for the care and use of animals were followed.

\section{Data Analyses}

We assessed the effects of the predictor variables (percent invasive species cover, plant species richness, percent shrub cover, percent bare ground, mean plant height, moon illumination, percent cheatgrass cover, and percent litter cover) on rodent richness and abundance using generalized linear mixed models (GLMMs) from the GLIMMIX procedure in SAS/STAT 13.2 in the SAS ${ }^{\circledR}$ System for Windows 9.4 TS1M2 (McCulloch and Neuhaus 2005, SAS Institute Inc. 2013). The trapping plot was used as the sampling unit for analysis, with 16 independent replications.

Because the same 16 plots were sampled over time (multiple times per year for 4 years), plot was fit as a random effect in all models. We checked continuous variables for collinearity using correlational analysis (we eliminated all pairs of variables with Pearson's $r$ indicating more than $30 \%$ correlation; Zar 2009). Mean plant height, percent shrub cover, and percent litter cover were arcsine squareroot transformed to improve normality. We included rodent richness and rodent abundance as continuous response variables in separate models, and the parameters percent invasive cover, mean plant height, percent shrub cover, percent moon illumination, percent litter cover, and plant richness were included as continuous predictor variables. Both models used a lognormal distribution. Effects of predictor variables were considered significant at a probability $(P)$ of $<0.05$; however, we also considered $P$ values in terms of relative evidence of difference and acknowledged this for $P$ values just above the cutoff of $P<0.05$ (Ramsey and Schafer 2002). Because the predictor variable invasive cover was of primary interest, we tested for a nonlinear relationship between response variables and invasive cover by including a quadratic (invasive cover $\times$ invasive cover interaction) term (Zar 2009) if invasive cover alone was not significant.

\section{REsUlTS}

Between May 2010 and September 2013, we conducted 9 trapping sessions and accumulated 4987 rodent captures over 28,224 trap nights. A total of 12 species were captured. In decreasing order of abundance, the following species were captured: Ord's kangaroo rat (Dipodomys ordii, 70.3\%), deer mouse (Peromyscus maniculatus, 15.6\%), chisel-toothed kangaroo rat (Dipodomys microps, 5.9\%), longtailed pocket mouse (Chaetodipus formosus, $3.2 \%$ ), northern grasshopper mouse (Onychomys leucogaster, 1.9\%), western harvest mouse (Reithrodontomys megalotis, 1.4\%), Great Basin pocket mouse (Perognathus parvus, $0.8 \%$ ), desert woodrat (Neotoma lepida, 0.2\%), piñon mouse (Peromyscus truei, $0.1 \%$ ), antelope ground squirrel (Ammospermophilus leucurus, $0.1 \%$ ), sagebrush vole (Lemmiscus curtatus, $<0.1 \%$ ), and little pocket mouse (Perognathus longimembris, $<0.1 \%$ ). There was an average of 8.8 nightly captures per plot, ranging from 0 to 29 nightly captures per plot. Plot richness ranged from 0 to 8 species with a mean richness of 2.6 species.

We detected 119 unique plant species across the 16 sampling plots. The percentage of invasive cover at these sites ranged from $3 \%$ to $99 \%$ with an average percent invasive cover of $48.8 \%$ (SD 29.27). In decreasing order of abundance, the following invasive plant species were encountered: cheatgrass $(59.5 \%)$, tall tumblemustard $(6.97 \%)$, and Russian thistle (5.02\%). The most commonly encountered noninvasive plant species were big sagebrush (7.48\%), Poa spp. (2.93\%), and Indian ricegrass (Achnatherum hymenoides, 1.9\%). Thus, the 3 invasive species comprised the first, second, and fourth most commonly observed plant species during the study.

Percent bare ground and percent cheatgrass cover were removed from the models due to collinearity with percent invasive cover. Percent invasive cover $(t=-2.6, \mathrm{df}=120$, $P=0.011$; Fig. 2) and moon brightness were found to be significant drivers of rodent richness (Table 1). There was suggestive evidence that rodent richness may have been influenced 


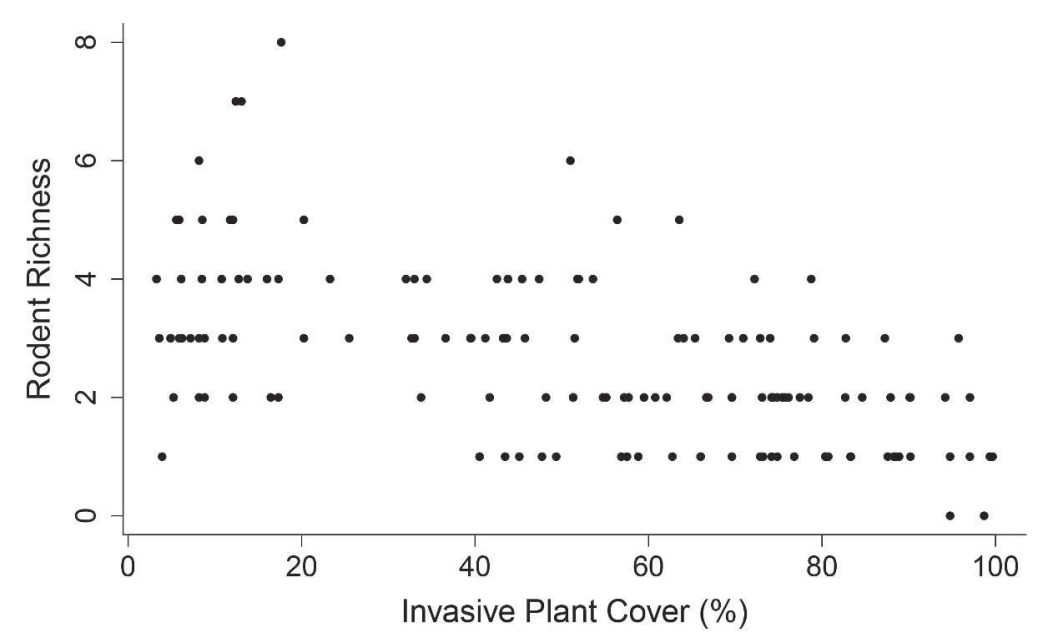

Fig. 2. Relationship between rodent richness (number of species encountered) and percent invasive plant cover on U.S. Army Dugway Proving Grounds, Utah, 2010-2013 ( $n=144$ plots).

TABLE 1. Results of GLMM for predictor variable effects on rodent richness, Dugway Proving Ground, Utah, 2010-2013 $(n=144)$.

\begin{tabular}{|c|c|c|c|c|}
\hline Predictor variable & Estimate & $\mathrm{SE}$ & $t$ & $P$ \\
\hline Mean plant height & 0.069 & 0.035 & 1.96 & 0.053 \\
\hline Percent invasive & -0.006 & 0.002 & -2.60 & $0.011^{*}$ \\
\hline Percent shrubs & 0.076 & 0.039 & 1.98 & 0.053 \\
\hline Moon brightness & -0.199 & 0.098 & -2.03 & $0.045^{*}$ \\
\hline Percent litter & 0.013 & 0.014 & 0.93 & 0.354 \\
\hline Plant richness & 0.002 & 0.013 & 0.13 & 0.895 \\
\hline
\end{tabular}

*Denotes significant $P$ values when $\alpha=0.05$.

TABLE 2. Results of GLMM for predictor variable effects on rodent abundance, Dugway Proving Ground, Utah, 2010-2013 $(n=144)$.

\begin{tabular}{lcccc}
\hline Predictor variable & Estimate & SE & $t$ & $P$ \\
\hline Mean plant height & -0.013 & 0.097 & -0.13 & 0.893 \\
Percent invasive & -0.005 & 0.006 & -0.84 & 0.402 \\
Percent invasive (quadratic) & -0.001 & 0.0002 & -4.07 & $<0.0001^{*}$ \\
Percent shrubs & 0.063 & 0.115 & 0.55 & 0.585 \\
Moon brightness & -0.663 & 0.248 & -2.67 & $0.009^{*}$ \\
Percent litter & 0.004 & 0.003 & -0.01 & 0.160 \\
Plant richness & -0.002 & 0.036 & & 0.953 \\
\hline
\end{tabular}

*Denotes significant $P$ values when $\alpha=0.05$.

by mean plant height $(t=1.96, \mathrm{df}=120, P=$ 0.053 ; Table 1) and percent shrub cover $(t=$ $1.98, \mathrm{df}=120, P=0.053$; Table 1$)$. Other vegetation structure parameters did not appear to influence rodent richness (Table 1). We found evidence of a nonlinear relationship between percent invasive cover and rodent abundance $(t=-4.07, \mathrm{df}=120, P<0.001$; Table 2, Fig. 3). Rodent abundance increased with increasing levels of invasive plant cover until a threshold was reached at approximately $48 \%$ invasive cover, after which rodent abundance decreased (Fig. 3). Moon illumination was a significant predictor of rodent relative abundance and exhibited a negative relationship $(t=-2.67$, df $=120, P=0.009$; Table 2 ). Other parameters were nonsignificant in the model (Table 2).

\section{Discussion}

Our results confirmed our prediction that invasive plant species would have a negative 


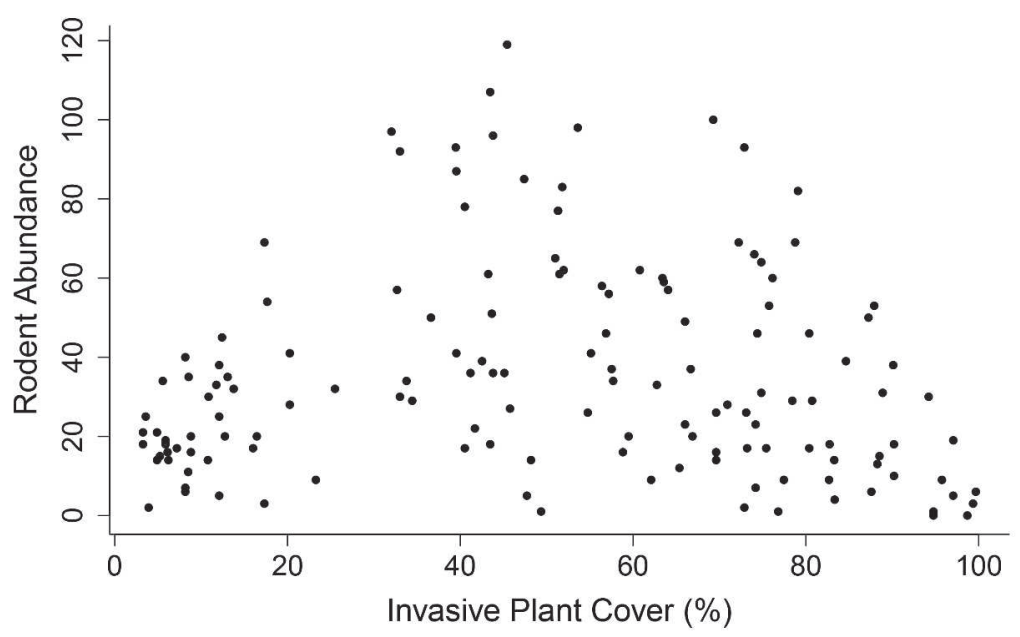

Fig. 3. Nonlinear relationship between rodent abundance (average nightly captures per session per plot) and percent invasive plant cover on U.S. Army Dugway Proving Grounds, UT, 2010-2013 ( $n=144$ plots).

influence on rodent species richness. This relationship was likely largely attributable to increasing cheatgrass cover, the most consistently dominant observed invasive, which homogenized habitat and reduced suitability for most rodent species. Researchers have repeatedly observed that rodent richness decreases with increasing cheatgrass cover throughout the Great Basin (Ostoja and Schupp 2009, Hall 2012, Freeman et al. 2014), but the additional effects of forbs such as Russian thistle and tall tumblemustard have not been examined exclusively. Percent cover of Russian thistle and tall tumblemustard in our plots was as high as $26 \%$ and $52 \%$, respectively. These invasive species may have had an additional effect on our observations. Although deer mice and Ord's kangaroo rat have demonstrated the ability to utilize habitat dominated by Russian thistle (Groves and Keller 1983), our findings suggest that invaded sites were not a suitable substitute for native habitat. These forbs are able to utilize soils with extremely low moisture (White 1985), and such dry soils can inhibit burrowing rodents (Sjoberg et al. 1984). Additionally, the observed pattern of reduced openness with increasing invasive species cover likely inhibited the movement of most species (Ostoja and Schupp 2009, Rieder et al. 2010, Hall 2012), which could have impacted vital rates, such as recruitment and survival, if individuals remained in the area. Alternatively, or concomitantly, generalists (such as deer mice) or species more transient in nature (Supp et al. 2015) may have emigrated to less invaded areas. Given that invasive cover was autocorrelated with bare ground and total cheatgrass cover, it is possible that one or both of these factors, rather than or in addition to invasive cover, could have driven our observed rodent responses.

Rodent forage availability was likely affected by the exotic plant invasion. Studies have shown that invaded sites feature reduced forage availability and habitat for rodent species (Knapp 1996, Ostoja and Schupp 2009). Kangaroo rats and deer mice are able to consume and cache cheatgrass seeds, but studies have shown that native consumers preferentially forage on native seeds over those of cheatgrass (Kelrick et al. 1986 [but see Jenkins 1988], Beard et al. 2013, Lucero et al. 2015). Similarly, some rodent species can utilize forage provided by Russian thistle, but will preferentially target easily available native forage when possible (McAdoo et al 1983, Longland 2007). Our vegetation data was not robust enough to examine the influence of each invasive plant species on rodent richness, nor did our investigation explicitly track seed consumption by rodents.

Although invasive cover appeared to be the strongest predictor of rodent richness, plant height and percent shrub cover may have also influenced this metric. Thompson and Gese (2013) linked landscape heterogeneity to community richness and found that plant height positively influenced rodent richness. Many 
quadruped rodents prefer to forage in areas with large amounts of cover, which is found in areas with higher plant height (Freeman et al. 2014). Thus, our observed decrease in species richness appeared to be driven by the changes prompted by the exotic invasion, including subsequent decreased cover (Knapp 1996), reduced heterogeneity (Thompson and Gese 2013), and reduced niche space for less abundant species (Freeman et al. 2014).

Our prediction that invasive plant cover would influence rodent abundance in a negative linear manner was not met. We feel our finding of a nonlinear relationship between invasive plant species and abundance of rodents supports the idea that rodent abundance in our study area actually increased with moderate levels of disturbance in the form of a cumulative plant invasion. This provides evidence for the intermediate disturbance hypothesis, given that a higher relative abundance was observed with moderate invasive cover. Due to the changes in cover and forage availability, along with a host of other changes to habitat composition, exotic plants are a large mechanism of disturbance (Knapp 1996, Thompson and Gese 2013, Freeman et al. 2014). Support for the intermediate disturbance hypothesis has been observed for several bird communities (Malavasi et al. 2009, Fischer et al. 2012, MacGregor-Fors et al. 2013), but rarely in rodent communities (Malick et al. 2012). We feel our observed increase may have been driven by Ord's kangaroo rat, the most abundant species during the study. Studies have shown that as an exotic plant invasion occurs, more intershrub space is created, which is commonly used more frequently by bipedal rodents, such as Ord's kangaroo rat, than by quadrupeds like the deer mouse (Thompson 1982, Freeman et al. 2014). In the same study area as ours and by using satellite-based landscape-level cover type classifications, Kluever et al. (2016) observed that rodents were more abundant in areas where exotic herbaceous vegetation was the dominant cover type compared to sagebrushdominated areas.

In addition to movement strategies, Ord's kangaroo rats create deep burrow complexes which are used to larder-hoard food (Jenkins and Breck 1998, Beck and Vander Wall 2010, White and Geluso 2012), escape physical weather conditions (White and Geluso 2012), and escape predation (Edelman 2011). Conversely, deer mice create nests above ground (Witmer and Moulton 2012) or use short burrows for protection ( $\mathrm{Hu}$ and Hoekstra 2017) and scatter-hoard food (Beck and Vander Wall 2010). Large burrow complexes, such as those utilized by kangaroo rats, are energetically costly to create (Vleck 1979), and kangaroo rats may inhabit invaded areas for longer due to an unwillingness to abandon an established burrow. Additionally, Ord's kangaroo rats have been shown to regularly consume and cache cheatgrass seeds (McMurray et al. 1997, Jenkins and Breck 1998). These seeds contain less protein but more carbohydrates than some native seeds (e.g., Indian ricegrass) and become far more abundant than native seeds as cheatgrass becomes established (Kelrick et al. 1986 [but see Jenkins 1988], Lucero et al. 2015). As such, the influx of low-quality but high-quantity forage available at intermediate levels of invasion may have resulted in increased resource availability for Ord's kangaroo rats. This resource influx, however, likely becomes overshadowed by the deleterious effects that accompany invasion severity once an invasion exceeds an intermediate level. It is also possible that a larger niche for Ord's kangaroo rat was created as shrub cover decreased with plant invasion and as other rodent species, primarily quadruped rodents from the Cricetidae family, experienced a marked reduction in abundance, emigrated to higher-quality habitat, or faced local extirpation.

Moon illumination was also a significant predictor of rodent abundance and richness. This result correlates with previous findings suggesting changes in foraging activity based on perceived vulnerability to predation (Orrock et al. 2004, Perea et al. 2011, Upham and Hafner 2013). In our study, moon illumination was not correlated with percent invasive cover, and moon illumination did not differ by plot or sampling session. As such, our results showed that the percentage of invasive cover was still a major driver of rodent community dynamics even after accounting for moon illumination.

Our study provides evidence that exotic invasions in the Great Basin Desert may have differential impacts on rodent community metrics at moderate levels of invasion. Freeman et al. (2014) and Ostoja and Schupp (2009) reported similar findings for species richness but observed a negative linear relationship for 
abundance of Great Basin rodents. Similarly, Hall (2012) observed a negative linear relationship between deer mouse abundance and exotic plant invasion. These somewhat contradictory findings appear to be driven by our study area being dominated by a bipedal rodent, whereas in other areas, Freeman et al. (2014) showed dominance of the deer mouse and Hall (2012) focused solely on the deer mouse. The deer mouse is likely more apt to vacate its burrow for more suitable habitat, which may be the reason for trends observed in prior studies. We speculate that the subsequent decrease in rodent abundance following a threshold of invasive disturbance was likely caused by the cumulative effects of decreased forage diversity and quality, obstruction and hindrance of movement, different seed-caching strategies, and raised predation risk-all factors that the remaining species could not cope with after invasive plants became the dominating plant feature. As such, there is a need for future rodent investigations to employ more experimentally robust designs that catalog rodent community metrics while manipulating invasive plant pervasiveness. Thus, careful consideration of the species comprising and dominating a rodent community is warranted when undertaking rodent-invasive plant investigations.

To our knowledge, we are the first to provide evidence for an intermediate response of a rodent community to exotic herbaceous invasion in a desert system. Because rodent biomass was highly correlated to rodent abundance in our study area, the prey base available to higher-trophic-level organisms that regularly consume Ord's kangaroo rats, like the kit fox (Vulpes macrotis; Kozlowski et al. 2008), a species of conservation concern, may peak in areas that have been moderately disturbed by invasive plant species. As such, if high total rodent abundance (i.e., biomass) is deemed an important ecological component or management/conservation goal for a community, the magnitude of invasive plant species eradication should be carefully considered in areas where kangaroo rats are or have the potential to be the most abundant rodent. However, if maintaining rodent diversity is considered more important, invasive plant species eradication and native species restoration should be a priority. Further, due to the tendency of invasive plant species encroachments to increase the frequency of fire disturbance and create complete monocultures, it is unlikely that a vegetation community intermediately disturbed by exotics could be maintained.

\section{ACKNOWLedgments}

Funding and logistical support was provided by the Department of Defense, U.S. Army Dugway Proving Ground, Environmental Programs, Dugway, Utah, and the USDA Wildlife Services, National Wildlife Research Center, Utah State University, Logan, Utah. Additional funding was provided by the Quinney College of Natural Resources, Utah State University, Logan, Utah; T\&E Inc.; the American Society of Mammologists; the Utah Chapter of The Wildlife Society; and the Endangered Species Mitigation Fund of the Utah Department of Natural Resources, Division of Wildlife Resources, Salt Lake City, Utah. We thank R. Knight for providing continual support for this research. We also thank S. Dempsey, B. Smith, A. Hodge, C. Crawford, L. Card, M. Cent, A. Reyer, C. Hansen, J. Fasig, W. Knowlton, W. Wright, C. Perkins, S. McEachin, J. DeCotis, and M. Richmond for field assistance. S. Durham provided invaluable support for statistical analyses.

\section{Literature Cited}

ArJo, W.M., E.M. Gese, T.J. Bennett, And A.J. Kolzowski. 2007. Changes in kit fox-coyote-prey relationships in the Great Basin Desert, Utah. Western North American Naturalist 67:389-401.

Balvanera, P., I. Siddique, L. Dee, A. Paquette, F. Isbell, A. Gonzalez, J. Byrnes, M.I. O'Connor, B.A. Hungate, AND J.N. GRIFFin. 2014. Linking biodiversity and ecosystem services: current uncertainties and the necessary next steps. BioScience 64:49-57.

Beard, K.H., C.A. Faulhaber, F.P. Howe, and T.C. EDWARDS JR. 2013. Rodent-mediated interactions among seed species of differing quality in a shrubsteppe ecosystem. Western North American Naturalist 73:426-441.

Beck, M.J., AND S.B. Vander WaLL. 2010. Seed dispersal by scatter-hoarding rodents in arid environments. Journal of Ecology 98:1300-1309.

Bowman, J., G. Forbes, and T. Dilworth. 2001. Landscape context and small-mammal abundance in a managed forest. Forest Ecology and Management 140:249-255.

Chambers, J.C. 2008. Invasive plant species and the Great Basin. USDA Forest Service, Rocky Mountain Research Station, Reno, NV.

Conard, J.M., J.A. Baumgard, P.S. GiPson, and D.P. Althoff. 2008. The influence of trap density and 
sampling duration on the detection of small mammal species richness. Acta Theriologica 53:143-156.

Edelman, A.J. 2011. Kangaroo rats remodel burrows in response to seasonal changes in environmental conditions. Ethology 117:430-439.

Emrick, V.A., AND A. Hill. 1999. Classification of Great Basin plant communities on Dugway Proving Ground, Utah. Construction Engineering Research Laboratories, Champaign, IL.

Fischer, R.A., J.J. Valente, M.P. Guilfoyle, M.D. Kaller, S.S. JaCKson, and J.T. RatTi. 2012. Bird community response to vegetation cover and composition in riparian habitats dominated by Russian olive (Elaeagnus angustifolia). Northwest Science 86:39-52.

Freeman, E.D., T.R. Sharp, R.T. Larsen, R.N. Knight, S.J. Slater, and B.R. McMillan. 2014. Negative effects of an exotic grass invasion on small-mammal communities. PLOS ONE 9(9): e108843.

Groves, C.R., AND B.L. Keller. 1983. Ecological characteristics of small mammals on a radioactive waste disposal area in southeastern Idaho. American Midland Naturalist 109:253-265.

HALL, L.K. 2012. Effect of cheatgrass on abundance of the North American deermouse (Peromyscus maniculatus). Southwestern Naturalist 57:166-169.

Hejda, M., P. Pysek, AND V. Jarosik. 2009. Impact of invasive plants on the species richness, diversity and composition of invaded communities. Journal of Ecology 97:393-403.

Herrick, J.E., J.W. Van Zee, K.M. Havstad, L.M. BurketT, AND W.G. WhitFord. 2005. Monitoring manual for grassland, shrubland, and savanna ecosystems. USDA-ARS Jornada Experimental Range, University of Arizona Press, Tucson, AZ.

Hu, K.H., and H.E. Hoekstra. 2017. Peromyscus burrowing: a model system for behavioral evolution. Seminars in Cell and Developmental Biology 61: 107-114.

Hu, Y., S. Magaton, G. Gillespie, and T.S. Jessop. 2013. Small reptile community responses to rotational logging. Biological Conservation 166:76-83.

Jenkins, S.H. 1988. Comments on relationships between native seed preferences of shrub-steppe granivores and seed nutritional characteristics. Oecologia 75: 481-482.

Jenkins, S.H., And S.W. Breck. 1998. Differences in food hoarding among six species of heteromyid rodents. Journal of Mammalogy 79:1221-1233.

Kaufman, D.W., and G.A. Kaufman. 1982. Effect of moonlight on activity and microhabitat use by Ord's kangaroo rat (Dipodomys ordii). Journal of Mammalogy 63:309-312.

Kelrick, M.I., J.A. Macmahon, R.R. Parmenter, and D.V. Sisson. 1986. Native seed preferences of shrub-steppe rodents, birds, and ants: the relationships of seed attributes and seed use. Oecologia 68:327-337.

Kelt, D.A. 2011. Comparative ecology of desert small mammals: a selective review of the past 30 years. Journal of Mammalogy 92:1158-1178.

Kluever, B.M., E.M. Gese, And S.J. Dempsey. 2016. The influence of wildlife water developments and vegetation on a rodent community in the Great Basin Desert. Journal of Mammalogy 97:1209-1218.

KNAPP, P.A. 1996. Cheatgrass (Bromus tectorum L) dominance in the Great Basin Desert: history, persistence, and influences to human activities. Global Environmental Change 6:37-52.

Kotler, B.P., J. Brown, S. Mukherjee, O. Berger-Tal, AND A. BouskiLA. 2010. Moonlight avoidance in gerbils reveals a sophisticated interplay among time allocation, vigilance and state-dependent foraging. Proceedings of the Royal Society B-Biological Sciences 277:1469-1474.

Kozlowski, A.J., E.M. Gese, and W.M. ARjo. 2008. Niche overlap and resource partitioning between sympatric kit foxes and coyotes in the Great Basin Desert of western Utah. American Midland Naturalist 160:191-208.

LitT, A.R., And D.E. Pearson. 2013. Non-native plants and wildlife in the Intermountain West. Wildlife Society Bulletin 37:517-526.

LONGLAND, W.S. 2007. Desert rodents reduce seedling recruitment of Salsola paulsenii. Western North American Naturalist 67:378-383.

Lucero, J.E., P.S. Allen, and B.R. McMillan. 2015. Increased primary production from an exotic invader does not subsidize native rodents. PLOS ONE 10(8): e0131564.

MacGregor-Fors, I., R. Ortega-Alvarez, A. BarreraGuzman, L. Sevillano, and E. Del Val de Gortari. 2013. Tama-risk? Avian responses to the invasion of saltcedars (Tamarix ramosissima) in Sonora, Mexico. Revista Mexicana de Biodiversidad 84:1284-1291.

Malavasi, R., C. Battisti, and G.M. Carpaneto. 2009. Seasonal bird assemblages in a Mediterranean patchy wetland: corroborating the intermediate disturbance hypothesis. Polish Journal of Ecology 57:171-179.

Malick, S.L., J.L. Belant, and J.G. Bruggink. 2012. Influence of spotted knapweed on diversity and abundance of small mammals in Grand Sable Dunes, Michigan, USA. Natural Areas Journal 32:398-402.

Malo, A.F., B. Godsall, C. Prebble, Z. Grange, S. McCandless, A. Taylor, and T. Coulson. 2013. Positive effects of an invasive shrub on aggregation and abundance of a native small rodent. Behavioral Ecology 24:759-767.

Mattos, K.J., And J.L. OrRok. 2010. Behavioral consequences of plant invasion: an invasive plant alters rodent antipredator behavior. Behavioral Ecology 21:556-561.

McAdoo, J.K., C.C. Evans, B.A. Roundy, J.A. Young, AND R.A. Evans. 1983. Influence of heteromyid rodents on Oryzopsis hymenoides germination. Journal of Range Management 36:61-64.

McCulloch, C.E., AND J.M. Neuhaus. 2005. Generalized linear mixed models. Encyclopedia of Biostatistics, volume 4. 2nd edition. Wiley.

McMurray, M.H., S.H. Jenkins, and W.S. Longland. 1997. Effects of seed density on germination and establishment of a native and an introduced grass species dispersed by granivorous rodents. American Midland Naturalist 138:322-330.

Niemi, G.J., AND M.E. McDonald. 2004. Application of ecological indicators. Annual Review of Ecology, Evolution, and Systematics 35:89-111.

OlfF, H., AND M.E. RitchiE. 1998. Effects of herbivores on grassland plant diversity. Trends in Ecology and Evolution 13:261-265.

Orrock, J.L., B.J. Danielson, and R.J. Brinkerhoff, 2004. Rodent foraging is affected by indirect, but not by direct, cues of predation risk. Behavioral Ecology 15:433-437. 
Ostoja, S.M., AND E.W. SCHupp. 2009. Conversion of sagebrush shrublands to exotic annual grasslands negatively impacts small mammal communities. Diversity and Distributions 15:863-870.

Pearson, D.E., and R.J. Fletcher. 2008. Mitigating exotic impacts: restoring deer mouse populations elevated by an exotic food subsidy. Ecological Applications 18:321-334.

Perea, R., R. Gonzalez, A. San Miguel, and L. Gil. 2011. Moonlight and shelter cause differential seed selection and removal by rodents. Animal Behaviour 82:717-723.

Ramsey, E.R., and D.W. Shafer. 2002. The statistical sleuth: a course in methods of data analysis. Duxbury Press, Pacific Grove, CA.

Reisner, M.D., J.B. Grace, D.A. Pyke, P.S. Doesher, AND A. SHEPPARD. 2013. Conditions favouring Bromus tectorum dominance of endangered sagebrush steppe ecosystems. Journal of Applied Ecology 50:1039-1049.

Rieder, J.P., T.A.S. Newbold, and S.M. Ostoja. 2010. Structural changes in vegetation coincident with annual grass invasion negatively impacts sprint velocity of small vertebrates. Biological Invasions $12: 2429-2439$

Roxburgh, S.H., K. Shea, and J.B. Wilson. 2004. The intermediate disturbance hypothesis: patch dynamics and mechanisms of species coexistence. Ecology 85:359-371.

SAS Institute Inc. 2013. SAS software. SAS Institute Inc., Cary, NC.

Sax, D.F., J.J. Stachowicz, J.H. Brown, J.F. Bruno, M.N. Dawson, S.D. Gaines, R.K. Grosberg, A. HastINGS, R.D. Holt, M.M. Mayfield, ET AL. 2007. Ecological and evolutionary insights from species invasions. Trends in Ecology and Evolution 22:465-471.

SIEG, C.H. 1987. Small mammals: pests or vital components of the ecosystem. Rocky Mountain Forest and Range Experimental Station, Rapid City, SD.

Sjoberg, D.E., J.A. Young, K. McAdoo, and R.A. Evans. 1984. Kangaroo rats. Rangelands 6:11-13.

Steidl, R.J., A.R. LitT, AND W.J. Matter. 2013. Effects of plant invasions on wildlife in desert grasslands. Wildlife Society Bulletin 37:527-536.

Supp, S.R., D.N. KoOnS, And S.K.M. ERnest. 2015. Using life history trade-offs to understand core-transient structuring of a small mammal community. Ecosphere 6:1-15.

Thompson, C.M., AND E.M. GESE. 2013. Influence of vegetation structure on the small mammal community in a shortgrass prairie ecosystem. Acta Theriologica 58:55-61.

Thompson, S.D. 1982. Microhabitat utilization and foraging behavior of bipedal and quadrupedal heteromyid rodents. Ecology 63:1303-1312.

Tilman, D., J. Knops, D. Wedin, P. Reich, M. Ritchie, And E. Siemann. 1997. The influence of functional diversity and composition on ecosystem processes. Science 277:1300-1302.

Upham, N.S., And J.C. Hafner. 2013. Do nocturnal rodents in the Great Basin Desert avoid moonlight? Journal of Mammalogy 94:59-72.

VLECK, D. 1979. The energy cost of burrowing by the pocket gopher Thomomys bottae. Physiological and Biochemical Zoology 52:122-136.

White J. 1985. The population structure of vegetation. Handbook of Vegetation Science. Series volume 3. Springer Netherlands, Dordrecht. 669 pp.

White, J.A., AND K. GELuso. 2012. Seasonal link between food hoarding and burrow use in a nonhibernating rodent. Journal of Mammalogy 93:149-160.

Witmer, G.W., and R.S. Moulton. 2012. Deer mice (Peromyscus spp.) biology, damage and management: a review. Pages 213-219 in Proceedings of the 25th Vertebrate Pest Conference. University of California, Davis, CA.

Yensen, D.L. 1981. The 1900 invasion of alien plants into southern Idaho. Western North American Naturalist 41:176-183.

Young, H.S., R. Dirzo, K.M. Helgen, D.J. McCauley, C.L. Nunn, P. Snyder, K.E. Veblen, S. ZhaO, and V.O. Ezenwa. 2016. Large wildlife removal drives immune defense increases in rodents. Functional Ecology 30:799-807.

Young, J.A., R.A. Evans, R.E. Eckert, and B.L. Kay. 1987. Cheatgrass. Rangelands 9:266-270.

Zar, J.H. 2009. Biostatistical analyses. Prentice Hall, Upper Saddle River, NJ.

Zeng, Z.G., J.H. Bi, S.R. Li, S.Y. Chen, D.A. Pike, Y. GAO, AND W.G. DU. 2014. Effects of habitat alteration on lizard community and food web structure in a desert steppe ecosystem. Biological Conservation 179:86-92.

Received 7 May 2017 Accepted 24 October 2017 Published online 24 January 2018 